\title{
Urban agriculture and Anopheles habitats in Dar es Salaam, Tanzania
}

\author{
Stefan Dongus ${ }^{1,2,3}$, Dickson Nyika ${ }^{3,4,5}$, Khadija Kannady ${ }^{4}$, Deo Mtasiwa ${ }^{4,6}$, Hassan \\ Mshinda $^{3}$, Laura Gosoniu ${ }^{1}$, Axel W. Drescher ${ }^{2}$, Ulrike Fillinger ${ }^{7}$, Marcel Tanner ${ }^{1}$, Gerry F. \\ Killeen $^{3,8,9}$, Marcia C. Castro ${ }^{10}$
}

${ }^{1}$ Department of Public Health and Epidemiology, Swiss Tropical Institute, University of Basel, P.O. Box, CH-4002 Basel, Switzerland; '2Department of Physical Geography, University of Freiburg, Werthmannstrasse 4, 79085 Freiburg, Germany; ${ }^{3}$ Ifakara Health Institute, Coordination Office, P.O. Box 78373, Kiko Avenue, Mikocheni B, Dar es Salaam, Tanzania; ${ }^{4}$ City Medical Office of Health, Dar es Salaam City Council, P.O. Box 63320, Dar es Salaam, Tanzania; ${ }^{5}$ Ministry of Agriculture and Food Security, P.O. Box 9192, Kilimo Road, Dar es Salaam, Tanzania; ${ }^{6}$ Ministry of Health and Social Welfare, P.O. Box 9083, Dar es Salaam, Tanzania; ${ }^{7}$ Disease Control and Vector Ecology Unit, London School of Hygiene and Tropical Medicine, Keppel Street, London, WC1E 7HT, UK; ${ }^{8}$ Institute of Ecosystems Science, School of Biological and Biomedical Sciences, Durham University, South Road, Durham, DH1 3LE, UK; ${ }^{9}$ Liverpool School of Tropical Medicine, Vector Group, Pembroke Place, Liverpool, L3 5QA, UK; ${ }^{10}$ Department of Population and International Health, Harvard School of Public Health, 665 Huntington Avenue, Boston, MA 02115, USA

\begin{abstract}
A cross-sectional survey of agricultural areas, combined with routinely monitored mosquito larval information, was conducted in urban Dar es Salaam, Tanzania, to investigate how agricultural and geographical features may influence the presence of Anopheles larvae. Data were integrated into a geographical information systems framework, and predictors of the presence of Anopheles larvae in farming areas were assessed using multivariate logistic regression with independent random effects. It was found that more than $5 \%$ of the study area (total size $16.8 \mathrm{~km}^{2}$ ) was used for farming in backyard gardens and larger open spaces. The proportion of habitats containing Anopheles larvae was 1.7 times higher in agricultural areas compared to other areas $(95 \%$ confidence interval $=1.56-1.92)$. Significant geographic predictors of the presence of Anopheles larvae in gardens included location in lowland areas, proximity to river, and relatively impermeable soils. Agriculture-related predictors comprised specific seedbed types, mid-sized gardens, irrigation by wells, as well as cultivation of sugar cane or leafy vegetables. Negative predictors included small garden size, irrigation by tap water, rainfed production and cultivation of leguminous crops or fruit trees. Although there was an increased chance of finding Anopheles larvae in agricultural sites, it was found that breeding sites originated by urban agriculture account for less than a fifth of all breeding sites of malaria vectors in Dar es Salaam. It is suggested that strategies comprising an integrated malaria control effort in malaria-endemic African cities include participatory involvement of farmers by planting shade trees near larval habitats.
\end{abstract}

Keywords: urban agriculture, Anopheles larvae, geographical information systems, malaria risk, malaria control, Tanzania.

Corresponding author:

Stefan Dongus

Department of Public Health and Epidemiology

Swiss Tropical Institute, University of Basel

P.O. Box, CH-4002, Basel, Switzerland

Tel. +41 61284 8283; Fax +41 612848105

E-mail: stefan.dongus@unibas.ch

\section{Introduction}

\section{Urban agriculture}

The consequences of rapid urbanisation pose enormous challenges for cities, particularly in devel- 
oping countries of sub-Saharan Africa. Challenges associated with such growth as seen there include high rates of unemployment and scarcity of adequate shelter, food, water, sanitation and environmental protection (Hardoy et al., 2001; UNFPA, 2007; UN, 2008; Harpham, 2009). One response to the increasing demands is urban and periurban agriculture, i.e. the production (from crop to animal production), processing and distribution of food within and around urban areas (Mougeot, 2000).

Farming in cities is a worldwide phenomenon (Smit et al., 1996), yet it has different functions in industrialised countries as compared to the developing ones. While its role has shifted to a mainly recreational one in the former, it remains an integral part of livelihood and food security in the latter (Drescher, 1998; Mougeot, 2000; Gerstl et al., 2002; Drescher et al., 2006). In Tanzania, the annual urban growth rate from 2005-2010 is projected to be $4.2 \%$ (UN, 2008) and urban agriculture (UA) appears to have developed and expanded in response to genuine need (Kyessi, 1997). People of varied socio-economic status levels practise UA throughout Tanzanian towns and cities (Sawio, 1993; Howorth et al., 2001).

In Dar es Salaam UA takes place on public land, private land, residential plots and industrial or institutional areas. In many cases, public land is used without formal agreement or illegally and without secure land rights (Jacobi et al., 2000). A large number of farmers of open spaces obtained their plots in the first half of the 1970s. During this period of economic crisis, the Tanzanian Government encouraged people in the city to cultivate every available piece of land (Stevenson et al., 1994). The decline of the economy worsened in the 1980s resulting in shortages of basic foodstuff. Urban dwellers responded by engaging in subsistence farming (Briggs, 1991) and by 1988, one in five people of working age in Dar es Salaam were involved in some form of UA (Smit et al., 1996). Currently, UA in Dar es Salaam consists of backyard gardening, livestock farming, community gardening, and market-oriented production on open spaces. Vegetables are the most important product (Jacobi et al., 2000) and most of the leafy vegetables consumed in Dar es Salaam comes from UA within the city (Stevenson et al., 1994). While backyard gardening is most important in terms of the number of households involved (Jacobi et al., $2000)$, open space production covers the largest area (4\% of the urban area in 1999) (Dongus, 2001). UA thus plays an important role in providing food, maintaining green areas, and generating income, yet it may also entail health risks. First, crops can be contaminated with heavy metals or pathogens from industrial or domestic wastewater, from urban solid waste used as fertiliser, or from agro-chemical poisoning (Birley and Lock, 1998). Second, UA can provide suitable conditions for mosquito larval development in stagnant water bodies created by irrigation, water storage and drainage, increasing the risk of vector-borne diseases such as malaria (Birley and Lock 1998; Keating et al., 2003, 2004; Afrane et al., 2004).

\section{Urban malaria}

Malaria accounts for approximately 1 million deaths worldwide each year, mainly in sub-Saharan Africa (Hay et al., 2005; Snow et al., 2005; WHO, 2008). The residents of Dar es Salaam are at risk of contracting malaria (Keiser et al., 2004) and belong to the estimated 2.4 billion of urban population living in areas where malaria transmission is dominated by Plasmodium falciparum, cause of the most lethal form of the disease (Guerra et al., 2008). In malaria-endemic areas, urbanisation has major implications for disease transmission patterns (Lines et al., 1994; Warren et al., 1999). Although vector density is typically much lower in urban areas compared to periurban and rural areas (Robert et al., 2003), malaria transmission is nevertheless a significant problem (Trape et al., 1993; Keiser et al., 2004; Donnelly et al., 2005; Hay et al., 2005). In Dar es Salaam, over a million malaria cases are reported by the health facilities every year (Mtasiwa et al., 2003) though malaria is often grossly over- 
reported (Makani et al., 2003; Wang et al., 2006; Reyburn et al., 2007), and a considerable part of the infections might result from travel to rural areas (Wang et al., 2006). Transmission is modest with one infectious bite per person per year, reflected by the moderate average prevalence of $12 \%$ (Geissbühler et al., 2009). In Dar es Salaam, 90\% of all malaria cases are caused by $P$. falciparum with the main vectors being Anopheles gambiae sensu strictu Giles, An. arabiensis Patton, An. funestus Giles and An. merus Dönitz (Castro et al., 2004). However, all Anopheles species found in Dar es Salaam are potential malaria vectors (Geissbühler et al., 2009).

\section{$U A$ and malaria}

The impact of UA on malaria transmission intensity in cities is not fully understood. In Kumasi, Ghana, higher adult anopheline densities were found in urban areas with agriculture than in those without. However, these UA areas were located in inland valleys that might have more mosquitoes due to their local ecology (Afrane et al., 2004). A report on malaria in Accra, Ghana, compared the prevalence in communities with and without UA concluding that proximity to irrigated, open-spaced, and commercial vegetable production may increase transmission (Klinkenberg et al., 2005), which could potentially play a role in malaria epidemiology (Klinkenberg et al., 2008). Other studies found that certain irrigation practices result in larger mosquito populations (Ijumba and Lindsay, 2001; Briet et al., 2003; Afrane et al., 2004; Dolo et al., 2004) but these do not necessarily lead to higher transmission levels (Ijumba and Lindsay, 2001; Dolo et al., 2004). In Bouaké, Côte d'Ivoire, Dossou-Yovo et al. (1994, 1998) found high anopheline densities but low sporozoite rates in areas bordering rice cultivation, concluding that rice fields did not seem to have notably modified malaria transmission. Robert et al. (1998) concluded from a study on market garden wells in Dakar, Senegal, that although wells served as breeding grounds for anophelines, these sites were not the only in sustaining the mosquito population. In Dar es Salaam, Wang et al. (2006) found that having a small urban agricultural land or garden near the living compound was not associated with malaria infection. However, these surveys were conducted after a long period of drought, when malaria prevalence was exceptionally low. The exact role of UA in malaria transmission thus remains unclear and needs further investigation (Afrane et al., 2004; Wang et al., 2006).

Anopheles breeding sites can be found in all kinds of urban land use, agricultural or not. A variety of studies have found that UA creates breeding sites for anophelines (Trape and Zoulani, 1987; Afrane et al., 2004; Matthys et al., 2006; Klinkenberg et al., 2008). However, a study in two Kenyan cities found no association between household level farming and vector breeding sites (Keating et al., 2004). Experiences in large-scale rice irrigation schemes in Mali showed the types and the density of breeding sites varied depending on the rice growing stages, and the related provision of shade (Klinkenberg et al., 2003). Therefore, water management such as intermittent irrigation as well as the adaptation of farming practices may significantly reduce the number of breeding sites in rice fields (van der Hoek et al., 2001; Keiser et al., 2002; Klinkenberg et al., 2003). In Dar es Salaam, Sattler et al. (2005) found that, where the groundwater table was high, seedbeds with small ridges tilled for growing plants with furrows dug between the ridges often contained shallow pools with Anopheles larvae. While rice fields, shallow wells and irrigation channels have also been found productive in this sense, malaria transmission in Dar es Salaam seems to be primarily associated with clusters of poorly drained and periurban areas, which often coincide with agricultural land use (Castro et al., 2004; Sattler et al., 2005).

This paper focuses on urban crop production investigating how the presence of Anopheles larvae is related to different UA characteristics as well as underlying geographical features in Dar es Salaam, Tanzania. 
Materials and methods

\section{Study area}

Dar es Salaam is the largest city and de facto capital of Tanzania with an estimated 2.9 million inhabitants in 2007 (UN, 2008). Situated on the shores of the Indian Ocean, large parts of the city are located on coastal plains that are interrupted by a number of river valleys. It has a hot and humid tropical climate with two rainy seasons and is characterised as an area with endemic and perennial malaria (MARA/ARMA, 2002). Although the conditions for agriculture are not particularly favourable in terms of soil types and fertility (Sawio, 1998), UA is widespread (Jacobi et al., 2000).

The city region covers an area of almost 1,400 $\mathrm{km}^{2}$ (Castro et al., 2004), divided into 73 administrative units called wards (Fig. 1). Three of those wards, Mikocheni, Buguruni and Kurasini, were chosen for sampling for this study. These areas are located within the urban area of Dar es Salaam between 1 and $10 \mathrm{~km}$ away from the city centre. The study area covers a total area of 16.8 $\mathrm{km}^{2}$ and a population of 128,000 (Fig. 2) (National Bureau of Statistics, 2003). Most of the area is built-up but provides nevertheless excellent breeding sites for mosquitoes with varied aquatic habitats for their eggs, larvae and pupae (Castro et al., 2004; Sattler et al., 2005; Fillinger et al., 2008). The choice of these wards rested on two main reasons: (i) they are representative of Dar es Salaam's geographic and socio-economic characteristics as well as of its urban land use (Dongus et al., 2007); and (ii) the relevant quality-controlled records of the distribution of aquatic-stage mosquitoes (Fillinger et al., 2008) are available from the Dar es Salaam Urban Malaria Control Programme (UMCP). This is the first operational community-based larviciding programme in modern Africa, described in detail elsewhere (Castro et al., 2004; Mukabana et al., 2006; Dongus et al., 2007; Fillinger et al., 2008).
The analysis is based on two datasets: (i) a specific UA survey, and (ii) the routine UMCP larval habitat survey (Fillinger et al., 2008).

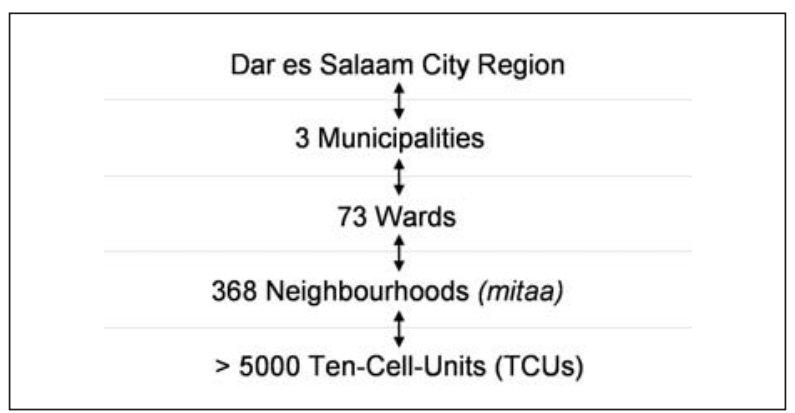

Fig. 1. Administrative levels and units in Dar es Salaam. Source: National Bureau of Statistics (2003). The number of TCUs is an estimation based on Dongus et al. (2007).

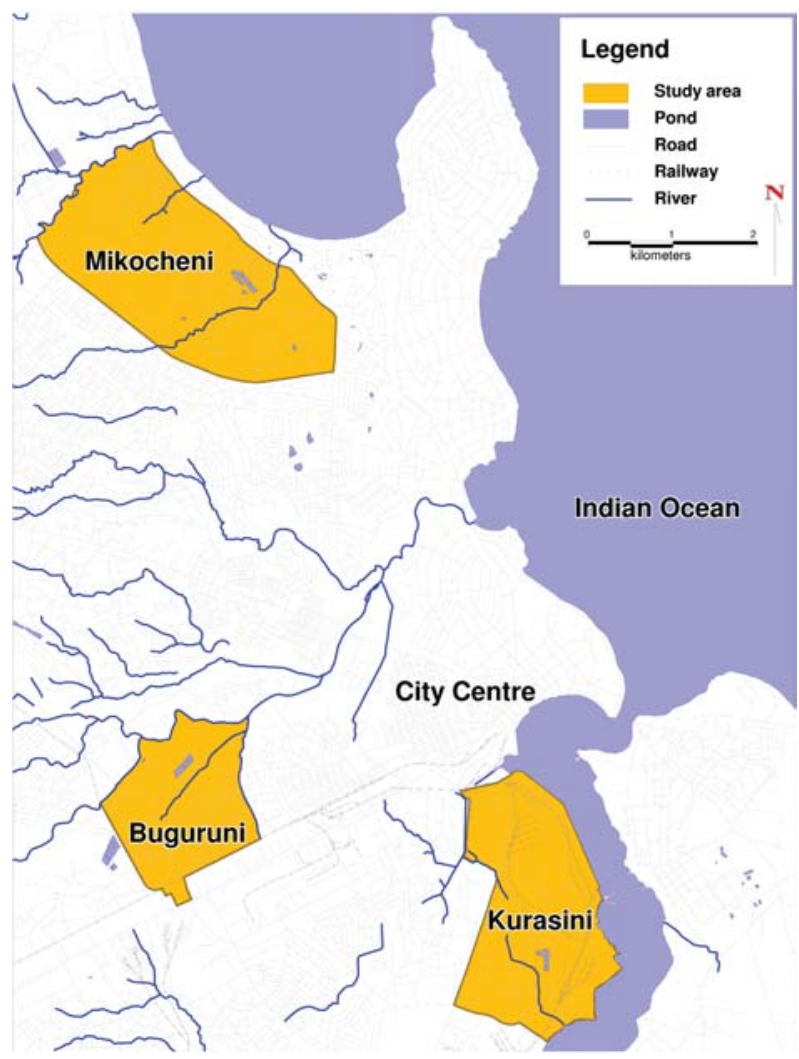

Fig. 2. Study area. Location of the three wards selected as study areas in Dar es Salaam: Mikocheni, Buguruni and Kurasini. 


\section{UA survey data}

Between late June 2005 and early January 2006, the three study wards were first visited and a crosssectional survey of all agricultural areas used for crop production was conducted. The survey was fully integrated into a participatory mapping of the UMCP target areas (Dongus et al., 2007), which was almost exclusively conducted during the dry periods. Data on agricultural characteristics (the variables are listed and explained in Tables 1 and 2) were collected using specific forms. The boundaries

Table 1. Geographical and agricultural explanatory variables which were tested regarding response variables denoting absence/presence of Anopheles larvae in agricultural areas.

\begin{tabular}{|c|c|c|}
\hline Explanatory variable & Categories/values & Explanations \\
\hline Topography & $\begin{array}{l}\text { Upland } \\
\text { Slope } \\
\text { Lowland }\end{array}$ & $\begin{array}{l}\text { Subjective categorisation done in the field, relative to surroundings within a dis- } \\
\text { tance of } 1 \mathrm{~km} \text {. Validated by visual interpretation of a digital elevation model** } \\
\text { (ITC Enschede and University of Dortmund, 2008). "Upland": higher or same } \\
\text { altitude than surroundings in all directions, "lowland": lower altitude than sur- } \\
\text { roundings in at least one direction, "slope": area between upland and lowland. }\end{array}$ \\
\hline Land use & $\begin{array}{l}\text { Informal settlement } \\
\text { Other urban or industrial } \\
\text { Planned residential } \\
\text { Vacant or agriculture }\end{array}$ & $\begin{array}{l}\text { Data from 2002, available as geographical information systems (GIS) } \\
\text { layer**. Selfexplaining category names. }\end{array}$ \\
\hline Ward & $\begin{array}{l}\text { Mikocheni } \\
\text { Buguruni } \\
\text { Kurasini }\end{array}$ & $\begin{array}{l}\text { The Dar es Salaam city region is subdivided into } 73 \text { wards. The three } \\
\text { "wards" included in this study are located in the urban part of the city } \\
\text { region (Fig. 1). Categories are the ward names. }\end{array}$ \\
\hline Farming site & $\begin{array}{l}\text { Backyard garden } \\
\text { Open space } \\
\text { Unbuilt plot or nursery }\end{array}$ & $\begin{array}{l}\text { "Backyard garden" (home garden): typically but not always near the home } \\
\text { of the gardener, within residential areas, generally for subsistence produc- } \\
\text { tion, maintained by individuals or households who have some access to land } \\
\text { (either customary or legal) which they have arranged for themselves } \\
\text { (Drescher et al., 2006). "Open space": public or private unbuilt land, for } \\
\text { example hazardous lands declared not suitable for construction, road and } \\
\text { railway reserves, available land for community use, as well as residential, } \\
\text { industrial or institutional plots under-utilised or awaiting development. } \\
\text { Open spaces are often used for agricultural activities, generally marketori- } \\
\text { ented production, and cultivated by more than one farmer (Dongus, 2001). }\end{array}$ \\
\hline Production type & $\begin{array}{l}\text { None } \\
\text { Raised beds (matuta) } \\
\text { Sunken beds } \\
\text { Mixed raised and sunken beds }\end{array}$ & $\begin{array}{l}\text { Describes any kind of seedbed arrangements. "None": plants grown on the } \\
\text { plain ground, "raised beds": plants grown on ridges with furrows in } \\
\text { between, usually to keep the roots dry, "sunken beds": seedbeds with slight- } \\
\text { ly raised borders, usually to maximise water use. }\end{array}$ \\
\hline Soil type & $\begin{array}{l}\text { Sandy } \\
\text { Loamy or clayey }\end{array}$ & $\begin{array}{l}\text { The soil type was determined by a simple finger test on the spot: rubbing the } \\
\text { soil between fingertips in order to assess the texture. Twenty-nine observa- } \\
\text { tions lack any data for this variable. }\end{array}$ \\
\hline Manure & $\begin{array}{l}\text { None } \\
\text { Cow, poultry, pig, goat or } \\
\text { other manure }\end{array}$ & $\begin{array}{l}\text { If a farmer was present, he or she was asked whether and what kind of } \\
\text { manure is used. If no one was present, the type of manure used was deter- } \\
\text { mined visually or by its typical smell. }\end{array}$ \\
\hline $\begin{array}{l}\text { Irrigation } \\
\text { source }\end{array}$ & $\begin{array}{l}\text { Well } \\
\text { Only rainfed } \\
\text { Tap water } \\
\text { Drain, ditch, standing } \\
\text { groundwater, river, stream } \\
\text { or other }\end{array}$ & $\begin{array}{l}\text { If a farmer was present, he or she was asked whether and what kind of irri- } \\
\text { gation is used. If no one was present, the irrigation type was determined } \\
\text { visually. }\end{array}$ \\
\hline
\end{tabular}




\begin{tabular}{|c|c|c|}
\hline Explanatory variable & Categories/values & Explanations \\
\hline Size & $\begin{array}{l}>400 \mathrm{~m}^{2} \\
101-400 \mathrm{~m}^{2} \\
\leq 1-100 \mathrm{~m}^{2}\end{array}$ & All agricultural areas were digitised in a GIS, so their exact sizes are known. \\
\hline $\begin{array}{l}\text { Distance to } \\
\text { rivers/streams }\end{array}$ & $\begin{array}{l}\leq 0-200 \mathrm{~m} \\
201-500 \mathrm{~m} \\
>500 \mathrm{~m}\end{array}$ & $\begin{array}{l}\text { Rivers/streams were digitised from the } 1992 \text { Dar es Salaam City Map } \\
\text { 1:20,000. Inaccuracies were corrected on the basis of the } 2002 \text { aerial photo- } \\
\text { graphs. Buffer zones corresponding to the distance categories (e.g. } \leq 200 \mathrm{~m} \text { ) } \\
\text { were assigned in the GIS. Agricultural areas were then assigned a certain dis- } \\
\text { tance category if their geometric centre (centroids) was located within the } \\
\text { respective buffer zone. }\end{array}$ \\
\hline $\begin{array}{l}\text { Distance to } \\
\text { drains }\end{array}$ & $\begin{array}{l}\leq 0-200 \mathrm{~m} \\
201-500 \mathrm{~m} \\
>\text { more than } 500 \mathrm{~m}\end{array}$ & $\begin{array}{l}\text { Drains were digitised from } 1992 \text { Cadastral Maps } 1: 2,500 \text {. Inaccuracies due to } \\
\text { new constructions were corrected on the basis of the } 2002 \text { aerial photographs } \\
\text { and Google Earth imagery. Buffer zones corresponding to the distance cate- } \\
\text { gories (e.g. } \leq 200 \mathrm{~m} \text { ) were assigned in the GIS. Agricultural areas were then } \\
\text { assigned a certain distance category if their geometric centre (centroids) was } \\
\text { located within the respective buffer zone. }\end{array}$ \\
\hline $\begin{array}{l}\text { Distance to } \\
\text { large standing } \\
\text { water bodies }\end{array}$ & $\begin{array}{l}\leq 0-200 \mathrm{~m} \\
201-500 \mathrm{~m} \\
>500 \mathrm{~m}\end{array}$ & $\begin{array}{l}\text { Standing water bodies were digitised from the } 1992 \text { Dar es Salaam City Map } \\
\text { 1:20,000. Inaccuracies e.g. due to new constructions were corrected on the } \\
\text { basis of the } 2002 \text { aerial photographs and Google Earth imagery. Buffer zones } \\
\text { corresponding to the distance categories (e.g. } \leq 200 \mathrm{~m} \text { ) were assigned in the } \\
\text { GIS. Agricultural areas were then assigned a certain distance category if their } \\
\text { geometric centre (centroids) was located within the respective buffer zone. }\end{array}$ \\
\hline Cereals* & Absent/present & Maize, sorghum \\
\hline Rice* & Absent/present & Rice \\
\hline $\begin{array}{l}\text { Leafy } \\
\text { vegetables* }\end{array}$ & Absent/present & E.g., Chinese cabbage, lettuce, spinach, sweet potato leaves, amaranth \\
\hline $\begin{array}{l}\text { Other } \\
\text { vegetables* }\end{array}$ & Absent/present & $\begin{array}{l}\text { E.g., cucumber, eggplant, tomatoes, watermelon, pumpkin, carrots, onion, } \\
\text { sweet pepper, hot pepper, okra }\end{array}$ \\
\hline Fruits* & Absent/present & $\begin{array}{l}\text { E.g., avocado, citrus, mango, pawpaw, pineapple, lemon, banana, cashew nuts, } \\
\text { guava, passion }\end{array}$ \\
\hline $\begin{array}{l}\text { Oilseed } \\
\text { crops* }\end{array}$ & Absent/present & E.g., coconuts, sunflowers, groundnuts \\
\hline Root crops* & Absent/present & Sweet potato, cassava, cassava leaves, yams \\
\hline $\begin{array}{l}\text { Leguminous } \\
\text { crops* }\end{array}$ & Absent/present & Cowpeas, pigeon peas \\
\hline Sugar cane* & Absent/present & Sugar cane \\
\hline Other crops* & Absent/present & E.g., flowers, tobacco, Guatemala grass \\
\hline
\end{tabular}

* Variables for crops assigned based on the "Indicative Crop Classification" (Food and Agriculture Organization of the UN) (FAO, 2005)

** Information provided by ITC Enschede and Dortmund University 
Table 2. Response variables for which geographical and agricultural explanatory variables were tested.

\begin{tabular}{lll}
\hline Response variable & Categories/values & Explanations \\
\hline Anopheles UA survey & Absent/present & $\begin{array}{l}\text { Presence of Anopheles larvae (any stage). Data source: UA survey. Not distin- } \\
\text { guishing seasons. }\end{array}$ \\
Anopheles UMCP & Absent/present & $\begin{array}{l}\text { Presence of Anopheles larvae (any stage). Data source: UMCP larval database. } \\
\text { Distinguishing wet and dry seasons. }\end{array}$ \\
Anopheles late UMCP & Absent/present & $\begin{array}{l}\text { Presence of late instar Anopheles larvae. Data source: UMCP larval database. } \\
\text { Distinguishing wet and dry seasons. }\end{array}$ \\
Pupae UMCP & Absent/present & $\begin{array}{l}\text { Presence of pupae (Anopheles and/or Culex). Data source: UMCP larval database. } \\
\text { Distinguishing wet and dry seasons. }\end{array}$ \\
\hline
\end{tabular}

of each agricultural area were indicated on laminated A4 colour prints (scale 1:3,000) of digital aerial photographs with a ground resolution $0.5 \mathrm{~m}$ (produced by Geospace International, Pretoria, South Africa in 2002). Water bodies located within the agricultural areas were surveyed for the presence of Anopheles larvae utilising the same standardised operational protocols as that adopted by the UMCP larval surveillance team (Fillinger et al., 2008). All data were digitised using the geographical information systems (GIS) software MapInfo Professional ${ }^{\circledR}$ 7.0 (MapInfo Corporation, Troy, NY, USA).

\section{UMCP larval habitat data}

The UMCP larval habitat data comprise comprehensive longitudinal larval surveillance information with one data entry per four week period (variables used in this study are described in Tables 1 and 2). The UMCP data were collected on an operational basis as described in detail by Fillinger et al. (2008). Larval catchers were trained and routine supervision and spot checks were undertaken to monitor and assure the quality of the information. The data were stored in databases created in EpiInfo ${ }^{\mathrm{TM}}$ software (Centers for Disease Control and Prevention (CDC), Atlanta, GA, USA), and double-entered.

\section{Linking of UA data and UMCP larval data}

In order to not only receive information about larval presence in the agricultural areas for one point in time, but for both the dry and wet seasons, the
UA survey data were matched with the UMCP larval data. The agricultural data of each area identified in the UA survey were matched with two observations from the UMCP larval database, representing data from the wet and dry seasons and collected nearest in time to the UA survey observation. This made it possible to incorporate the aspect of rainfall seasonality into the cross-sectional data. All UMCP larval observations, made between March 2005 and February 2006, were assigned either to a wet or a dry season period based on daily rainfall data from the Tanzania Meteorological Agency (http://www.meteo.go.tz) collected at the Dar es Salaam airport station. The wet season periods (average weekly rainfall above $25 \mathrm{~mm}$ ) included March 9-May 28, 2005; October 18-November 25, 2005; and February 12-28, 2006. The dry season periods (average weekly rainfall below $2.5 \mathrm{~mm}$ ) included May 29-October 17, 2005; and November 26, 2005 to February 11, 2006 (Fig. 3). The maximum time between the UA survey and the corresponding UMCP larval data was one month or less in $87 \%$ of the UMCP dry season observations (median = 12 days), and three months or less in $88 \%$ of the UMCP wet season observations (median $=59$ days).

The UA survey found a total of 623 agricultural areas in the study area, with sizes ranging from 10 to almost $66,000 \mathrm{~m}^{2}$, covering a total area of $0.9 \mathrm{~km}^{2}$. From these, 201 areas had to be dropped because no observations were available for them in the UMCP larval database. These areas were mostly rainfed small gardens located in upland or slope areas (Fig. 


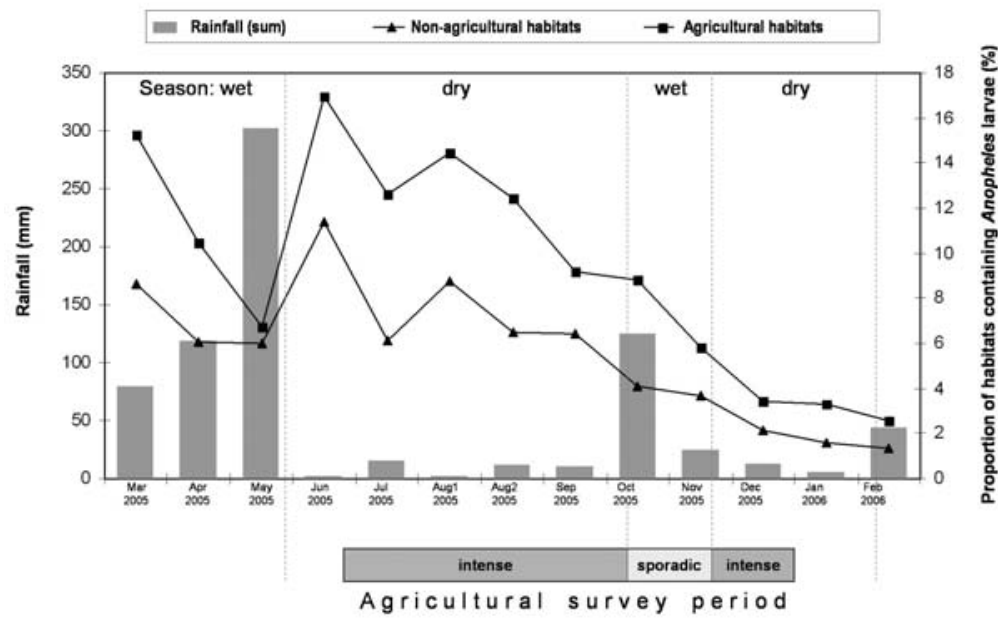

Fig. 3. Seasonality and proportions of habitats with Anopheles larvae. X-axis: period of the UMCP larval data and the UA survey. Y-axis: rainfall in $\mathrm{mm}$ (grey bars); proportions of habitats containing Anopheles larvae in agricultural areas (upper line) and non-agricultural areas (lower line). Larval proportions are based on UMCP larval data.

6A). In addition, 17 gardens were excluded because they only had observations for one of the two seasons. Another 33 areas had to be excluded because their corresponding UMCP larval data only covered periods after the commencement of larvicide use in March 2006 (Fillinger et al., 2008; Geissbühler et al., 2009). Unfortunately, these 33 areas, located in the valley of the Msimbazi River in Buguruni, constituted the largest agricultural cluster in the study area. Hence, the study sample comprised 372 individual agricultural areas covering a total of $0.2 \mathrm{~km}^{2}$ (covering $1.2 \%$ of the total surface of the study area).

\section{Geographical data}

Available geographical data were assembled. Some of these were used for visual interpretation (e.g. roads and railway lines), while other data were utilised for statistical analysis (e.g. land use and hydrological information). Land use classes and distances to hydrological features (e.g. rivers) were assigned based on the centroid locations (geometric centres) of each agricultural area. In order to determine the distances, buffer zones were assigned around the various hydrological features (Table 1).
A digital elevation model (DEM) was used for visual interpretation and validation of the topographical data collected in the UA survey. The DEM as well as the roads and land use data were provided by the International Institute for Geo-Information Science and Earth Observation (ITC) Enschede, The Netherlands, and the University of Dortmund, Germany (2008).

\section{Statistical methods}

Statistical analysis was done with the STATA ${ }^{\circledR}$ software (version 9.0, Stata Corporation, College Station, TX, USA), and complemented with visual interpretation of maps produced with MapInfo and ArcGIS (version 9.2, ESRI, Redlands, CA, USA). Multiple models were fitted using a stepwise (backward selection and inclusion criteria: $\mathrm{P}<0.2)$ multivariate, logistic regression procedure with independent random effects. The following statistical model specifications were employed:

Let $Y_{i}$ be the binary response corresponding to the presence of Anopheles larvae at site $i, i=1, \ldots, n$ taking value $=1$ if Anopheles larvae are present and the value $=0$ otherwise. Let $X_{i}=\left(X_{i 1}, \ldots, X_{i p}\right)^{T}$ be the 
vector of $p$ associated geographical and agricultural predictors observed at location $i$. We assume that $Y_{i}$ are Bernoulli distributed $Y_{i} \sim \operatorname{Ber}\left(p_{i}\right)$ with a presence probability $p_{i}$ given by the equation

$$
\log \text { it }\left(p_{i}\right)=\beta_{0}+\sum_{j=1}^{p} X_{i j} \beta_{j}
$$

To take into account potential clustering, random effects $\varepsilon_{i}$ were introduced at each site $i$, that is

$$
\log i t\left(p_{i}\right)=\beta_{0}+\sum_{j=1}^{p} X_{i j} \beta_{j}+\varepsilon_{i}
$$

The " $\varepsilon_{i}$ " values were assumed independent and were modelled with a mean $=0$ normal distribution with the variance $\tau^{2}$.

The response variables for all models denoted presence or absence of (i) Anopheles larvae, (ii) late instar (development stage) Anopheles larvae, and (iii) pupae of any kind of mosquito species. Three response variables were based on UMCP larval data, distinguishing wet and dry seasons, and one response variable was exclusively based on UA survey data. Almost all $(99 \%$; n = 367) of the UA survey observations were made in the dry season, with only $1 \%(\mathrm{n}=5)$ in the wet season (see Tables 1 and 2 for a list and description of the explanatory and response variables). Because of the small sample size, data from individual wards were combined in one model. Correlations between explanatory variables were assessed using Fisher and $\chi^{2}$ tests. Interaction terms between production type and types of crops were included in the regression models to test for heterogeneity in the effect of various crops.

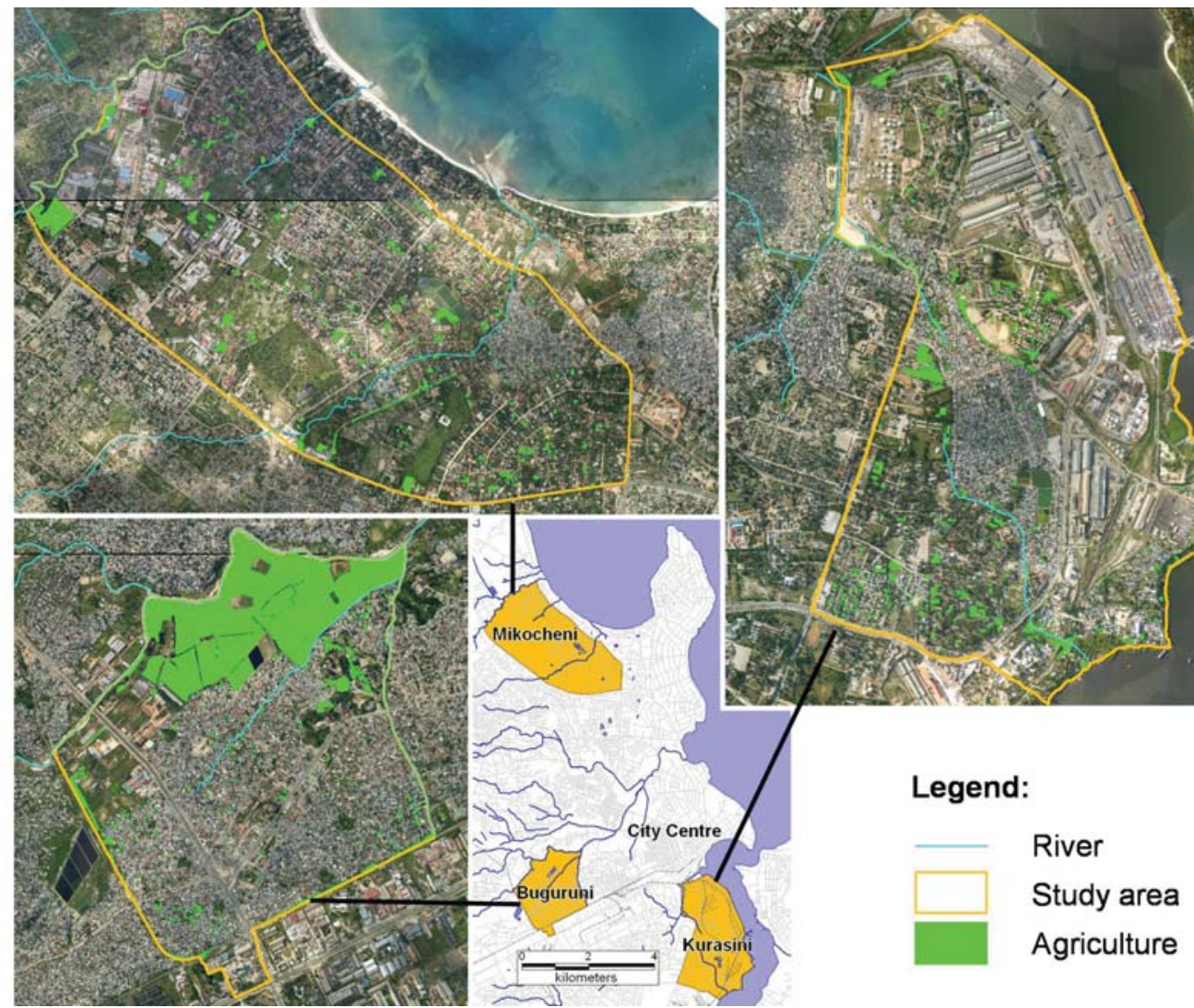

Fig. 4. Map of urban agricultural areas in Dar es Salaam. Location and extent of urban agricultural areas in the three study wards. Background: aerial image from 2002. 


\section{Results}

\section{Typology of agricultural areas}

The UA survey revealed that a total of $0.9 \mathrm{~km}^{2}$ equal to $5.5 \%$ of the study area was used for urban crop farming at the time of the study. The most common farming sites were backyard gardens and open spaces (Table 1 and Fig. 4). Garden sizes ranged from as little as $15 \mathrm{~m}^{2}$ to $15,000 \mathrm{~m}^{2}$ (mean = $550 \mathrm{~m}^{2}$, median $\left.=202 \mathrm{~m}^{2}\right)$. In planned residential areas large backyard gardens were most common, while small backyard gardens were more common in informal settlements. Areas designated for industrial purposes were often used for open-space farming. Less than $10 \%$ of all gardens were found in vacant land not considered to be part of residential or industrial areas. Most gardens were located in upland areas $(70 \%)$, mainly with sandy soils. Half of the gardens in the lowland areas had loamy or clayey soils. Proximity to rivers was neither correlated to number of nor to sizes of gardens.

Slightly more than half of all gardens were irrigated. The non-irrigated gardens were particularly seen in informal settlements which thus relied on rainfall for water. Otherwise, $30 \%$ of the gardens were irrigated with tap water, which was the most common source of irrigation in planned residential areas, while $20 \%$ used dug earth wells or cemented ones as source of irrigation. Water from rivers, drains and standing groundwater was utilised in only $4 \%$ of all cases. In more than a third of the gardens, some kind of manure was applied as fertiliser with poultry and cow dung being the most popular ones. Almost two-thirds of all gardens, and more than $80 \%$ of those in informal settlements smaller than $100 \mathrm{~m}^{2}$, did not have any specific production type; there were no seedbed arrangements and crops were simply planted into the plain soil. In contrast, $18 \%$ of the gardens consisted of sunken beds only, $13 \%$ of raised beds only, and another $4 \%$ had both sunken and raised beds.

The most common classes of crops grown were vegetables (leafy as well as non-leafy), fruit and root crops, that were found in about $60 \%$ of all gardens. Leguminous crops (42\%), sugar cane $(24 \%)$ and cereals $(23 \%)$ were also frequently present. Oilseed crops were found in $7 \%$ of all gardens. Only $1 \%$ of gardens grew rice but this picture would have been different in the wet season when rice production is popular, especially in the river valleys. In most gardens, three or more different crop classes were present.

\section{$U A$ and Anopheles larvae}

The UMCP survey results, which were linked to the UA survey data, found Anopheles larvae in $11 \%$ of all plots with agriculture during the wet periods, and in $17 \%$ of all plots (subunits of tencell-units; Dongus et al., 2007) with agriculture during the dry periods. The UA survey, mostly conducted during dry periods, showed a lower level of occupancy with Anopheles larvae (12\%). The discrepancies may be a result of small temporal variations in larval density. Figure 3 shows the seasonality observed in the UMCP larval dataset and the period of the agricultural survey. Figure 5 shows a map of the agricultural areas with and without Anopheles larvae.

The largest number of breeding sites with Anopheles larvae in Dar es Salaam was not found to be related to agriculture but instead to drains, ditches, swamps and puddles in non-agricultural areas. During March 2005 to February 2006, 11\% of all water bodies found by the UMCP in the studied wards were located in agricultural areas and $17 \%$ of all habitats containing Anopheles larvae were found in those areas. Therefore, although agricultural areas were not the most frequent potential habitat, they were more productive than the others. This is illustrated by the finding that throughout all seasons of the year, the proportion of habitats containing Anopheles larvae was higher in plots with agriculture compared to plots without agriculture. The average proportion over the year was 1.7 times higher in agricultural plots $(95 \%$ confidence interval $(\mathrm{CI})=1.56-1.92)$. Figure 3 shows the propor- 

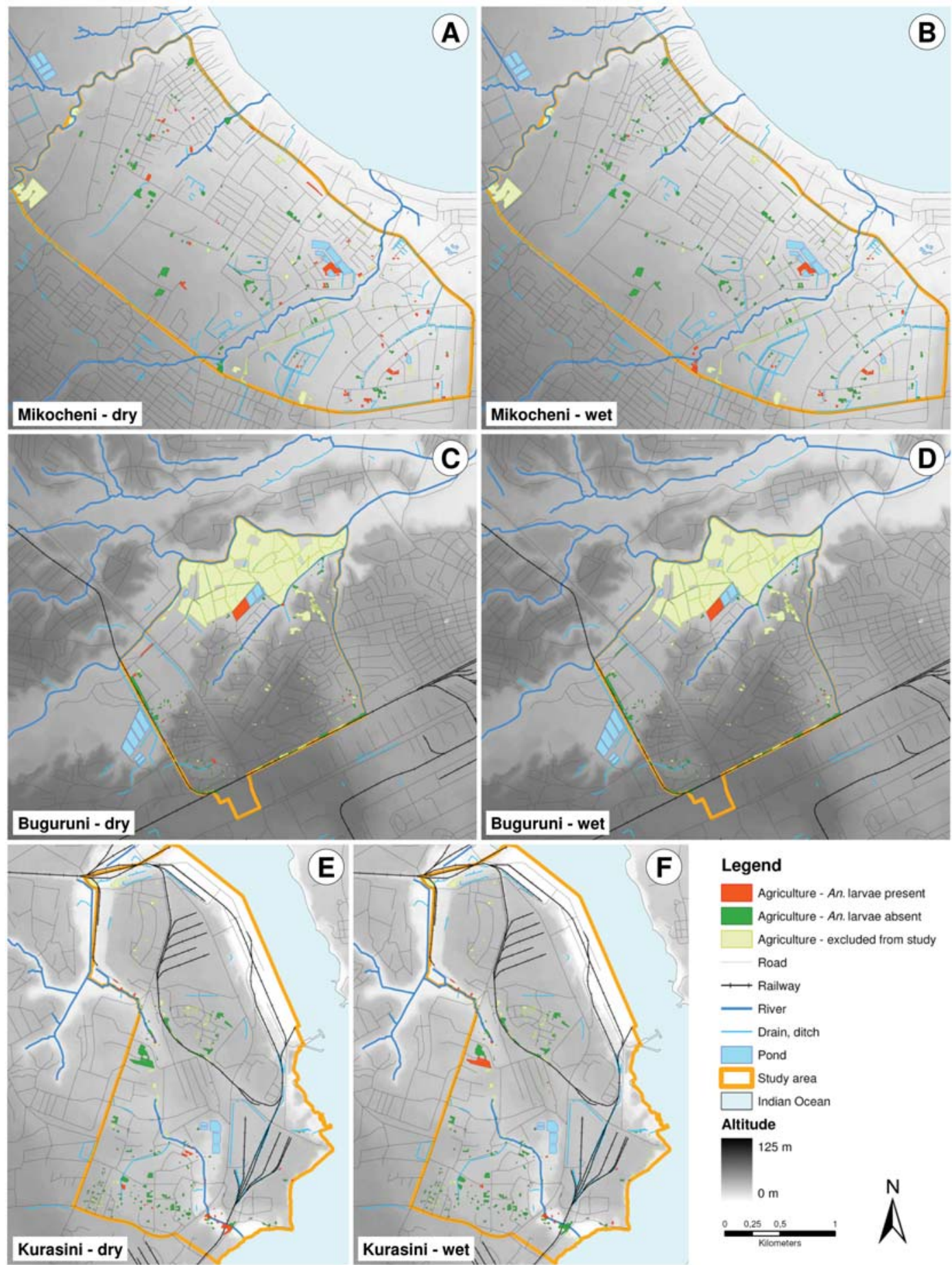

Fig. 5. Agricultural areas and Anopheles larvae. Map of agricultural areas in the three study wards, indicating presence (red) and absence (dark green) of Anopheles larvae in the wet and the dry season periods, as well as agricultural areas excluded from the study (light green). Results from UA survey and UMCP larval data are combined. 
tions of habitats containing larvae among all habitats plotted against those found in agricultural plots.

\section{Geographical features}

Topography, location, hydrology and soil type were the most significant geographical features associated with the presence of Anopheles larvae. Plots with farming in lowland areas were far more likely to contain breeding sites with Anopheles larvae than upland farming areas (dry season: odds ratio $(\mathrm{OR})=14.56 ; 95 \% \mathrm{CI}=4.02-52.82$; $\mathrm{P}<0.001$ ) (Tables 3 and 4). Compared to the Mikocheni ward, the odds of finding Anopheles larvae were lower in the Buguruni gardens (dry season: $\mathrm{OR}=0.02 ; 95 \% \mathrm{CI}=0.00-0.11 ; \mathrm{P}<0.001)$, and also in Kurasini. During the dry season, the chance of finding late instar Anopheles larvae decreased at distances further than $500 \mathrm{~m}$ away compared to distances less than $200 \mathrm{~m}$ away from rivers $(\mathrm{OR}=$ $0.20 ; 95 \%$ CI $=0.06-0.63 ; \mathrm{P}=0.006)$. A similar relation applied for ponds. Gardens on loamy and clayey soils showed a higher chance for Anopheles larvae than those on sandy soils (OR $=9.28 ; 95 \%$ $\mathrm{CI}=3.05-28.18 ; \mathrm{P}<0.001)$. Regarding land use, gardens in planned residential areas had the lowest odds for late instar Anopheles larvae (wet season: $\mathrm{OR}=0.14 ; 95 \%$ CI $=0.02-0.93 ; \mathrm{P}=0.042)$. Gardens in industrial areas and vacant land, not designated for any kind of construction purposes, were not significant.

\section{Agricultural features}

Gardens that fully relied on rainfall had a much lower chance to contain Anopheles larvae compared to gardens with any type of well for irrigation (Fig. 6D) (dry season: $\mathrm{OR}=0.22 ; 95 \% \mathrm{CI}=0.06-0.73$; $\mathrm{P}=0.013$ ). Approximately half of the agricultural breeding sites that contained Anopheles larvae in the UA survey were wells. The odds were even lower where tap water was used for irrigation (dry season: $\mathrm{OR}=0.16 ; 95 \% \mathrm{CI}=0.04-0.58 ; \mathrm{P}=0.005$; wet season: late instar: $\mathrm{OR}=0.09 ; 95 \% \mathrm{CI}=0.01-0.55 ; \mathrm{P}$
$=0.009)$. Although only approaching significance because of the low number of observations, other irrigation sources such as water from drains/ditches and standing groundwater in agricultural areas seemed to greatly increase the probability of Anopheles larvae presence.

While the exclusive presence of raised beds (matuta in Kiswahili, i.e. ridges for planting crops such as sweet potato that are often made on grounds with a high water table) was significant only regarding pupae (wet season: $\mathrm{OR}=3.0 ; 95 \%$ $\mathrm{CI}=1.06-8.48 ; \mathrm{P}=0.038)$, plots with only sunken beds were associated with a higher probability of Anopheles breeding in the dry season $(\mathrm{OR}=5.37$; $95 \% \mathrm{CI}=1.52-18.95 ; \mathrm{P}=0.009 ;$ all compared to gardens without any kind of seedbed arrangements). Plots with mid-sized gardens (101-400 $\left.\mathrm{m}^{2}\right)$ had a higher chance of late instar Anopheles larvae compared to larger agricultural areas (dry season: $\mathrm{OR}=4.50 ; 95 \% \mathrm{CI}=1.49-13.56 ; \mathrm{P}=0.008)$. The smallest odds were found in small gardens of $100 \mathrm{~m}^{2}$ maximum size (dry season: $\mathrm{OR}=0.08$; $95 \% \mathrm{CI}=0.01-0.82 ; \mathrm{P}=0.034)$.

The growing of sugar cane $(\mathrm{OR}=4.25 ; 95 \%$ $\mathrm{CI}=1.37-13.21 ; \mathrm{P}=0.012)$ and leafy vegetables in the dry season was associated with relatively high odds of larvae presence (though less with regard to vegetables). However, the cultivation of leguminous crops (wet season: late instar OR $=0.25 ; 95 \%$ $\mathrm{CI}=0.08-0.81 ; \mathrm{P}=0.020)$ was correlated with a relatively low probability of larvae presence. Although not significant, the same may apply for the cultivation of fruit (dry season: $\mathrm{OR}=0.37 ; 95 \% \mathrm{CI}=0.13$ 1.05; $\mathrm{P}=0.062)$. Oilseed crops such as coconut trees, root crops, non-leafy vegetables and other crops were not significant. Crop diversity lead to different results depending on the season, i.e. in the dry season, the chance to find larvae decreased where three or more crop classes were present within an agricultural area, whereas the opposite was the case during the wet season. Lastly, interaction terms between type of production and type of crop were not significant, suggesting that there was no heterogeneity in the effect of varied crops. 
Table 3. Results of multivariate logistic regression models (dry season).

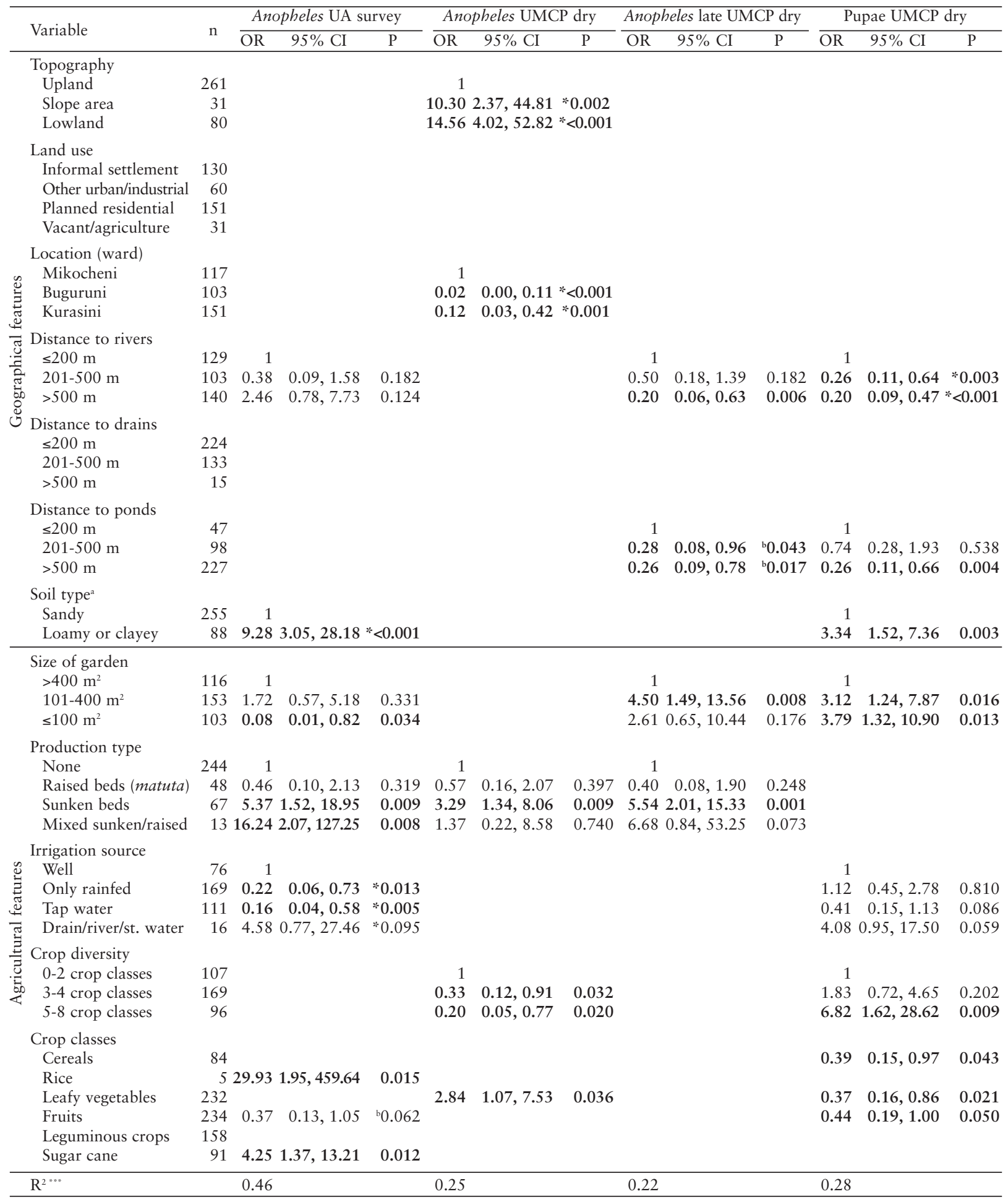


Table 4. Results of multivariate logistic regression models (wet season).

\begin{tabular}{|c|c|c|c|c|c|c|c|c|c|c|c|}
\hline & \multirow{2}{*}{ Variable } & \multirow[b]{2}{*}{$\mathrm{n}$} & \multicolumn{3}{|c|}{ Anopheles UMCP wet } & \multicolumn{3}{|c|}{ Anopheles late UMCP wet } & \multicolumn{3}{|c|}{ Pupae UMCP wet } \\
\hline & & & OR & $95 \% \mathrm{CI}$ & $\mathrm{P}$ & OR & $95 \% \mathrm{CI}$ & $\mathrm{P}$ & OR & $95 \% \mathrm{CI}$ & $\mathrm{P}$ \\
\hline \multirow{28}{*}{ 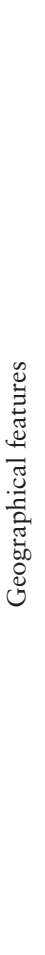 } & Topography & & & & & & & & & & \\
\hline & Upland & 261 & 1 & & & & & & & & \\
\hline & Slope area & 31 & 0.21 & $0.00,16.29$ & 0.479 & & & & & & \\
\hline & Lowland & 80 & 24.80 & $0.46,1349.15$ & 0.115 & & & & & & \\
\hline & Land use & & & & & & & & & & \\
\hline & Informal settlement & 130 & 1 & & & 1 & & & & & \\
\hline & Other urban/industrial & 60 & 26.46 & $0.51,1380$ & 0.104 & 1.44 & $0.32,6.52$ & 0.635 & & & \\
\hline & Planned residential & 151 & 1.36 & $0.08,22.34$ & 0.831 & 0.14 & $0.02,0.93$ & 0.042 & & & \\
\hline & Vacant/agriculture & 31 & 1.11 & $0.05,25.28$ & 0.946 & 0.92 & $0.20,4.34$ & 0.919 & & & \\
\hline & Location (ward) & & & & & & & & & & \\
\hline & Mikocheni & 117 & 1 & & & & & & & & \\
\hline & Buguruni & 103 & 0.00 & $0.00,1.35$ & $* 0.060$ & & & & & & \\
\hline & Kurasini & 151 & 0.24 & $0.01,3.77$ & $* 0.307$ & & & & & & \\
\hline & Distance to rivers & & & & & & & & & & \\
\hline & $\leq 200 \mathrm{~m}$ & 129 & & & & & & & 1 & & \\
\hline & $201-500 \mathrm{~m}$ & 103 & & & & & & & 0.27 & $0.10,0.74$ & 0.011 \\
\hline & $>500 \mathrm{~m}$ & 140 & & & & & & & 0.25 & $0.10,0.60$ & 0.002 \\
\hline & Distance to drains & & & & & & & & & & \\
\hline & $\leq 200 \mathrm{~m}$ & 224 & 1 & & & & & & & & \\
\hline & $201-500 \mathrm{~m}$ & 133 & 0.34 & $0.05,2.49$ & 0.287 & & & & & & \\
\hline & $>500 \mathrm{~m}$ & 15 & 111.92 & $0.29,42537$ & 0.120 & & & & & & \\
\hline & Distance to ponds & & & & & & & & & & \\
\hline & $\leq 200 \mathrm{~m}$ & 47 & & & & & & & & & \\
\hline & $201-500 \mathrm{~m}$ & 98 & & & & & & & & & \\
\hline & $>500 \mathrm{~m}$ & 227 & & & & & & & & & \\
\hline & Soil type ${ }^{a}$ & & & & & & & & & & \\
\hline & Sandy & 255 & & & & & & & & & \\
\hline & Loamy or clayey & 88 & & & & & & & & & \\
\hline \multirow{26}{*}{ 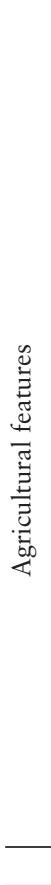 } & Size of garden & & & & & & & & & & \\
\hline & $>400 \mathrm{~m}^{2}$ & 116 & & & & & & & & & \\
\hline & $101-400 \mathrm{~m}^{2}$ & 153 & & & & & & & & & \\
\hline & $\leq 100 \mathrm{~m}^{2}$ & 103 & & & & & & & & & \\
\hline & Production type & & & & & & & & & & \\
\hline & None & 244 & & & & & & & 1 & & \\
\hline & Raised beds (matuta) & 48 & & & & & & & 3.00 & $1.06,8.48$ & 0.038 \\
\hline & Sunken beds & 67 & & & & & & & 3.60 & $1.53,8.44$ & 0.003 \\
\hline & Mixed sunken/raised & 13 & & & & & & & 8.56 & $1.87,39.23$ & 0.006 \\
\hline & Irrigation source & & & & & & & & & & \\
\hline & Well & 76 & 1 & & & 1 & & & & & \\
\hline & Only rainfed & 169 & 0.41 & $0.05,3.48$ & 0.415 & 0.26 & $0.05,1.35$ & $* 0.109$ & & & \\
\hline & Tap water & 111 & 0.02 & $0.00,1.64$ & 0.080 & 0.09 & $0.01,0.55$ & $* 0.009$ & & & \\
\hline & Drain/river/st. water & 16 & 6.03 & $0.19,187.3$ & 0.305 & 3.18 & $0.67,15.13$ & $* 0.146$ & & & \\
\hline & Crop diversity & & & & & & & & & & \\
\hline & $0-2$ crop classes & 107 & & & & 1 & & & & & \\
\hline & 3-4 crop classes & 169 & & & & 5.89 & $1.01,34.25$ & ${ }^{c} 0.048$ & & & \\
\hline & 5-8 crop classes & 96 & & & & 16.01 & $1.74,147.1$ & ${ }^{\mathrm{c}} 0.014$ & & & \\
\hline & Crop classes & & & & & & & & & & \\
\hline & Cereals & 84 & & & & & & & & & \\
\hline & Rice & 5 & & & & & & & & & \\
\hline & Leafy vegetables & 232 & 10.29 & $0.60,176.17$ & 0.108 & & & & & & \\
\hline & Fruits & 234 & & & & & & & & & \\
\hline & Leguminous crops & 158 & & & & 0.25 & $0.08,0.81$ & 0.020 & 0.38 & $0.17,0.85$ & 0.019 \\
\hline & Sugar cane & 91 & & & & & & & 2.89 & $1.31,6.36$ & 0.009 \\
\hline & $\mathrm{R}^{2 \ldots \infty}$ & & 0.28 & & & 0.33 & & & 0.15 & & \\
\hline
\end{tabular}


Legend to Tables 3 and 4.

Multivariate logistic regression models after stepwise selection of variables, with independent random effects. OR $=$ odds ratio, $95 \%$ $\mathrm{CI}=95 \%$ confidence interval, $\mathrm{P}=$ p-value. Results are only shown for variables with $\mathrm{P}<0.05$ in the likelihood-ratio-test. Bold: $\mathrm{P}<0.05$.

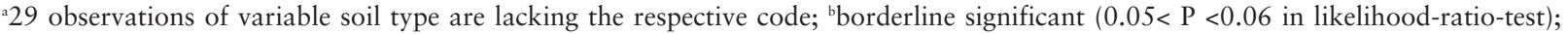
clikelihood-ratio-test does not converge, but variable is significant in model without random effect, same OR and p-values; * variables with $\mathrm{P}<0.001$ in likelihood-ratio-test; $* *$ taken from corresponding multivariate logistic regression model without independent random effect.

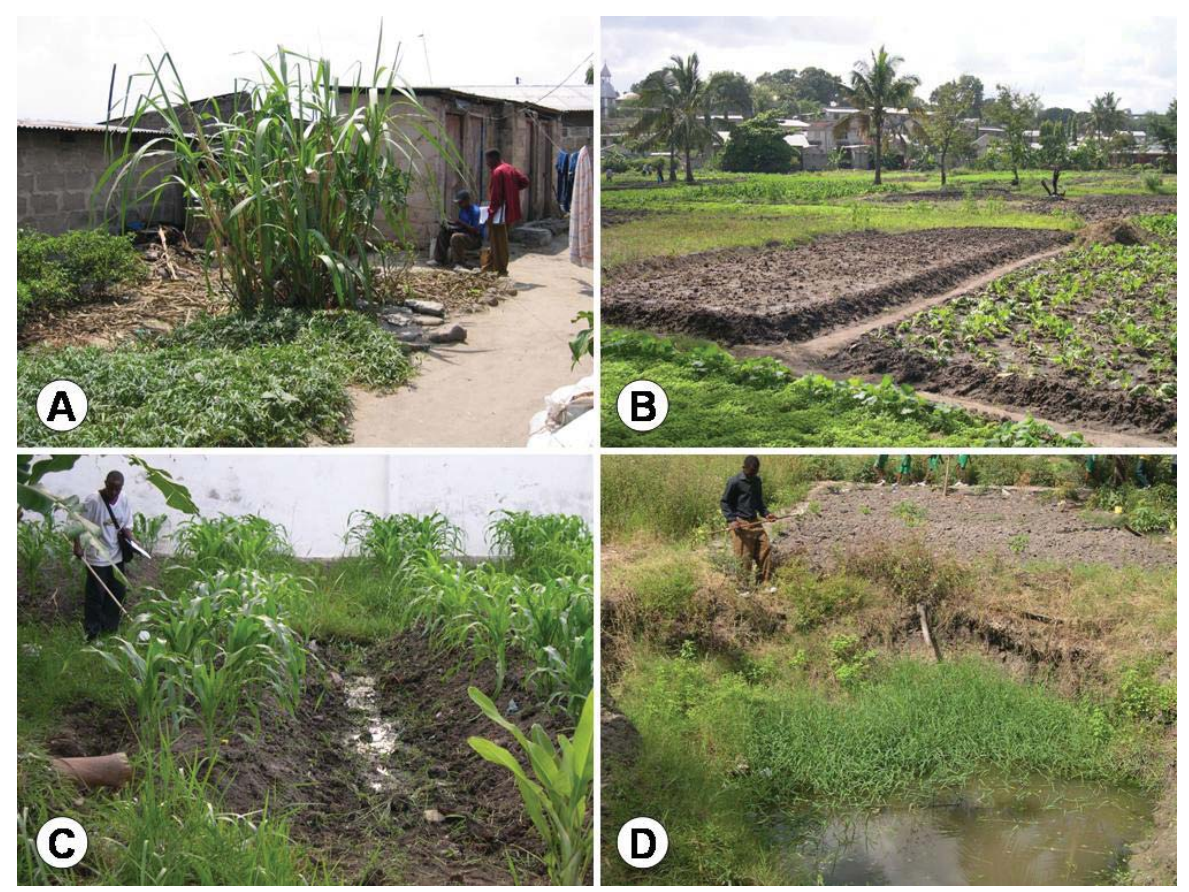

Fig. 6. (A) small rainfed backyard garden in Buguruni, upland location in informal settlement, sandy soil, no seedbed arrangements, visible crops: leafy vegetables and sugar cane; (B) large open space garden in Buguruni (river valley), lowland area, loamy soil, sunken beds, visible crops: leafy vegetables, oilseed crops, fruit; (C) raised beds (matuta) with standing water between ridges in Mikocheni, visible crops: cereals and fruit; (D) dug well for irrigation in Buguruni, lowland area.

\section{Discussion}

UA is only one among many other types of land use that can enable larval development of Anopheles mosquitoes in cities. More than $80 \%$ of all habitats with Anopheles larvae in urban Dar es Salaam are located in areas without agricultural activities. However, farming and the presence of Anopheles larvae are correlated. Cultivated areas are 1.7 times more likely than others to contain breeding habitats with Anopheles larvae. In order to explore the underlying reasons that lead to this situation, factors related to presence of Anopheles larvae in UA areas were investigated. Apart from geographical factors that have been examined previously (Balls et al., 2004; Sattler et al., 2005; Matthys et al., 2006; Zhou et al., 2007; Majambere et al., 2008), a range of agricultural features at a partly unprecedented level of detail in terms of crops was included in the analysis. Moreover, to our knowledge, this is the first comprehensive mapping of UA in an African city, notably the inclusion of backyard gardens.

Compared to findings from mountainous areas (Balls et al., 2004; Cohen et al., 2008), this study reveals that topography matters even at differences less than $10 \mathrm{~m}$. As a matter of principle, the topography corresponds with the hydrological conditions in an area. Rivers and streams accumulate fine 
grained soil particles in their floodplains. Loamy and clayey soils are thus usually found in lowlands, whereas more permeable sandy soils are more frequent in upland areas. The groundwater table is generally higher in lowland areas compared to their surroundings. Therefore, areas in lowlands and in close proximity to rivers or ponds are more likely to contain breeding sites than others. This was particularly obvious in Kurasini (Fig. 5). All factors mentioned are beneficial for agriculture, and therefore likely to be a main reason for the presence of agriculture in the first place, particularly the case in floodplains that are unsuitable for construction purposes. One can argue that such local ecological conditions are simultaneously ideal for both Anopheles larvae and for agriculture. Recent evidence from coastal towns in Kenya supports this finding, showing that agriculture per se had no detectable influence when such environmental variables were controlled for (Keating et al., 2004). Furthermore, environmental variables such as shade, substrate and vegetation were the best predictors for the presence of the three major vector species in these urban centres (Jacob et al., 2005). Untouched by any human activity, the natural vegetation of such areas may provide less favourable conditions for Anopheles larvae (Lindblade et al., 2000; Munga et al., 2006), especially if closed leafy canopies or other vegetation of sufficient density prevent sunlight from reaching the soil. The only natural vegetation still existing in our study area occurred in a few isolated mangroves in Kurasini.

Different geographic and socio-economic characteristics of the three areas investigated may explain the distinct results for each ward. Mikocheni had the highest odds of finding gardens with larvae. This might be explained by its very homogenous topography with limited surface runoff, and thus higher impact of loamy and clayey soils. The gardens in Mikocheni were relatively large in size as enough space was available in undeveloped industrial plots and backyards in planned residential areas. In contrast to the other two wards, the larval data for Mikocheni used in the analysis were predominantly from the first half of the agricultural survey, coinciding with a period of relatively high larval densities (Fig. 3). Buguruni showed the lowest odds of finding larvae. To a large extent this can be explained by the fact that the large agricultural area located in the river valley that contains many potential habitats had to be excluded from the analysis. This valley serves as natural drainage for the remaining parts of the ward, mostly upland areas with permeable sandy soils and limited space for gardens due to the dense informal settlement structure. Kurasini had the most diverse terrain and the highest impact from topography. The fact that the probability to find larvae in gardens was found to be lower than in Mikocheni may be explained by the different runoff situation that concentrates surface and ground water to particular areas and the less favourable water-holding capacity by the predominantly sandy soils $(89 \%$ of gardens in Kurasini, only $45 \%$ in Mikocheni). Another reason might be pollution by the petrol and harbour industry in Kurasini.

Agriculture using raised beds (matuta) (Fig. 6C) had no significant impact. This cannot be explained by accidental disproportionate exclusion of such areas in the analysis, such as the large areas in the river valley in Buguruni. In fact, the excluded observations actually had a lower proportion of areas with raised beds $(8 \%, \mathrm{n}=19)$ than those included $(13 \%, \mathrm{n}=48)$. The presence of sunken beds with slightly raised borders to maximise water use (Fig. $6 \mathrm{~B})$, however, was clearly correlated to increased presence of larvae. Importantly, in plots with sunken or raised beds, most of the larvae were in wells and not found in seedbeds or in the ridges between them. Nevertheless, considering contrary previous findings (Sawio 1998; Castro et al., 2004, Sattler et al. 2005), the importance of raised beds as Anopheles breeding sites should not be underestimated.

Dug earth wells (Fig. 6D) often contained Anopheles larvae, especially if they were large enough to allow parts of the surface to remain undisturbed by irrigation activities. The largest risk factor related to irrigation, however, seemed to be a 
groundwater table at such a high level that surface water does not drain away or evaporate for long periods. The majority of gardens in such areas contained Anopheles larvae. Soil moisture in general has been shown to play a crucial role (Patz et al., 1998). In contrast, purely rainfed gardens and those that are irrigated all year long by tap water were very unlikely to contain larvae suggesting minimal malaria risk. Although water in blocked drains or ditches sometimes contains Anopheles larvae, it is often polluted and a typical breeding site for Culex larvae, which probably contributes to the high odds of finding pupae in such habitats.

The size of an agricultural area appears to be a logical factor contributing to larval presence, as the likelihood of finding breeding sites increases with the size of an area. At the same time, the size of a garden is related to the number of farmers. While gardens less than $400 \mathrm{~m}^{2}$ in size are usually cultivated by one farmer, open spaces are often cultivated by several farmers jointly, especially if larger than 1,000 $\mathrm{m}^{2}$ (Jacobi et al., 2000; Dongus, 2001). In Dar es Salaam, while gardens with a size below $100 \mathrm{~m}^{2}$ had a significantly smaller probability to contain larvae compared to larger gardens, the most likely gardens to have larvae were the mid-sized ones $\left(100-400 \mathrm{~m}^{2}\right)$ rather than the largest ones. A possible explanation for this observation might be the intensive use of irrigation in large agricultural areas where several farmers often share the same well. The water in such a well is disturbed much more frequently than in gardens cultivated by only one farmer making it a less attractive breeding site for Anopheles. This might also explain why areas with a high crop diversity have relatively high odds of Anopheles larvae in the wet season. These generally large areas require less irrigation in the wet season as compared to the dry season, which probably results in less frequent use of the wells. Therefore, the garden size might at the same time reflect an impact of the number of farmers using it.

Some crops are known to be associated with Anopheles proliferation, irrigated rice in particular (Dossou-Yovo et al., 1994; Dolo et al., 2004;
Mboera et al., 2007; Sogoba et al., 2007). The results of this study probably underestimate the impact of rice cultivation for two reasons. First, the UA survey was mostly conducted during the dry season, when most of the numerous and large rice fields in Dar es Salaam are lying fallow, resulting in a sample size of rice fields $(n=5)$ too small to show any significant correlation. Second, almost all large rice growing areas had to be excluded from the study due to reasons explained in the material and methods section; therefore their impact during the wet season could not be measured. Cereals have been discussed by other authors regarding pollen of a certain variety of maize as a nutrition basis for larvae (Ye-Ebiyo et al., 2003) and in terms of increased malaria incidence (Kebede et al., 2005). Although there is a common belief that malaria vector mosquitoes breed in the leaf axils of maize plants, it has been shown that they do not (Birley and Lock, 1998). The only link our study could establish was that presence of cereals in a garden resulted in a reduced probability of finding pupae. This was also seen with respect to leafy vegetables, leguminous crops and fruit. The reason behind may be the clean environment that especially larger gardens often imply. Raised beds are often planted with root crops such as sweet potatoes in Dar es Salaam and have been suspected of being important Anopheles breeding sites as mentioned above (Castro et al., 2004). In this study, however, root crops did not influence the probability of finding Anopheles larvae. Sweet potatoes were planted in raised beds in $70 \%$ of the cases. Sugar cane cultivation and presence of larvae as well as pupae were positively correlated, presumably because of the high water requirements of this crop. However, another study in Tanzania found that irrigated sugar cane production does not have any negative impact (Ijumba et al., 2002). Where leafy vegetables and larvae were both found in one place, this was mostly due to the presence of wells ensuring regular irrigation of these crops. Leafy vegetables irrigated with tap water or which are directly rainfed were rarely related to habitats. Leguminous crops, and to some extent fruit trees, were negative- 
ly related to larval presence. The cultivation of leguminous crops such as cowpeas may therefore be an indicator for dry areas that are unlikely to contain breeding sites. In the case of fruit trees, the shade provided by their leafy canopies might even be a factor reducing the suitability of water bodies as Anopheles breeding sites.

In summing up the findings above, it should be stated that the characteristics of gardens with high odds of containing Anopheles larvae comprised the following: a location in lowland areas, proximity to rivers or ponds, loamy or clayey soils, sunken beds, sizes between 100-400 $\mathrm{m}^{2}$ (and therefore only one user), wells, and with regard to crops, the cultivation of sugar cane or leafy vegetables. Urban gardens with relatively low odds of containing Anopheles breeding sites were characterised by an upland location (unless there is a lack of runoff), sandy soils, informal and planned settlements, large distance to rivers and ponds, absence of wells, irrigation by tap water or rainfed production, no specific seedbeds, very small or very large size (unless there are rice fields in the wet season) and cultivation of leguminous crops or fruit trees.

The identified characteristics of gardens with the highest potential to host Anopheles breeding sites bear important implications for malaria control. Their features make it relatively easy to identify and access them. The majority of gardens possessed few of these characteristics, and many had none of them at all. An integrated vector control programme could consider two strategies. First, farmers could be trained and actively involved in environmental vector control (Sawio 1998; Mlozi et al., 2006; Mboera et al., 2007), for example by establishing farmer field schools (van den Berg and Knols, 2006; van den Berg et al., 2007) targeting farmers in agro-ecosystems most at risk of anopheline breeding. Agricultural extension services might play an important role in this respect, for example by promoting locally tailored environmental management practices such as planting of fruit trees as an additional crop to provide shade over water bodies (WHO, 1982; Rafatjah, 1988; Walker and Lynch, 2007) and by combining agriculture and forestry (agroforestry) in general (Swallow and Ochola, 2006). Shading wells could potentially eliminate this important Anopheles breeding site. Second, when needed, systematic larviciding should be used and targeted to productive habitats, particularly where environmental management practices cannot be applied.

Although there is an increased probability of finding Anopheles larvae in agricultural sites, breeding sites originated by UA account for less than $20 \%$ of all breeding sites of malaria vectors in Dar es Salaam in terms of their total number. UA thus is not the main reason for the presence of breeding Anopheles larvae and therefore malaria transmission in Dar es Salaam. Nevertheless, agriculture-related breeding habitats do have a high presence of larvae, and therefore represent a potential malaria risk factor that thoroughly needs to be considered by vector control programmes. Strategies comprising an integrated malaria control effort in malaria-endemic African cities may include involvement of farmers by planting shading trees near larval habitats.

\section{Ethical considerations}

This study did not involve human subjects. Research clearance was obtained from the Medical Research Coordination Committee of the National Institute for Medical Research in Tanzania (NIMR/HQ/R.8a/Vol. IX/279) and the Tanzanian Commission of Science and Technology (No. 2005-123-NA2004-163 and No. 2006-115-ER-2004-163). This manuscript is published with kind permission of the Director of the National Institute for Medical Research of Tanzania, Dr Andrew Kitua. In order to achieve community consent and before starting any field work, the stakeholders and community leaders at the respective local government units were contacted. The goals of the activity were explained, and the survey team was introduced. All responsible UMCP staff members were present in such meetings.

\section{Acknowledgements}

We would like to thank the community members of the study areas in Dar es Salaam (Mikocheni, Buguruni and 
Kurasini wards) and all members of the UMCP involved in the implementation of this study. We thank the Photogrammetry Unit at the Surveys and Mapping Division of the Ministry of Lands in Tanzania for providing us the digital aerial imagery used in this study. Further thanks go to the late Michael Kiama who was one of the initiators of the UMCP, as well as Brigit Obrist, Penelope Vounatsou, Ben Moon and Aisha Msonde for their various inputs. We thank Richard Sliuzas (ITC Enschede) and the University of Dortmund for kindly providing a DEM and other GIS data of Dar es Salaam. The underlying research was financially supported by the Bill and Melinda Gates Foundation; the United States Agency for International Development through its Environmental Health Project, its Dar es Salaam mission and the President's Malaria Initiative; Valent BioSciences Corporation; the Swiss Tropical Institute; and the Wellcome Trust through Research Career Development Fellowship number 076806 to GFK. SD was funded by the Swiss National Centre of Competence in Research (NCCR) North-South.

\section{References}

Afrane YA, Klinkenberg E, Drechsel P, Owusu-Daaku K, Garms R, Kruppa T, 2004. Does irrigated urban agriculture influence the transmission of malaria in the city of Kumasi, Ghana? Acta Trop 89, 125-134.

Balls MJ, Bodker R, Thomas CJ, Kisinza W, Msangeni HA, Lindsay SW, 2004. Effect of topography on the risk of malaria infection in the Usambara Mountains, Tanzania. Trans R Soc Trop Med Hyg 98, 400-408.

Birley MH, Lock K, 1998. Health and peri-urban natural resource production. Environ Urban 10, 89-106.

Briet OJT, Dossou-Yovo J, Akodo E, van de Giesen N, Teuscher TM, 2003. The relationship between Anopheles gambiae density and rice cultivation in the savannah zone and forest zone of Côte d'Ivoire. Trop Med Int Health 8, 439-448.

Briggs J, 1991. The peri-urban zone of Dar es Salaam, Tanzania: recent trends and changes in agricultural land use. T I Brit Geogr 16, 319-331.

Castro MC, Yamagata Y, Mtasiwa D, Tanner M, Utzinger J, Keiser J, Singer BH, 2004. Integrated urban malaria control: a case study in Dar es Salaam, Tanzania. Am J Trop Med Hyg 71, 103-117.
Cohen JM, Ernst KC, Lindblade KA, Vulule JM, John CC, Wilson ML, 2008. Topography-derived wetness indices are associated with household-level malaria risk in two communities in the western Kenyan highlands. Malar J 7, 40.

Dolo G, Briet OJT, Dao A, Traore SF, Bouare M, Sogoba N, Niare O, Bagayogo M, Sangare D, Teuscher T, Toure YT, 2004. Malaria transmission in relation to rice cultivation in the irrigated Sahel of Mali. Acta Trop 89, 147-159.

Dongus S, 2001. Urban vegetable production in Dar es Salaam (Tanzania) - GIS-supported analysis of spatial changes from 1992 to 1999. In: Drescher AW and Mäckel R (Eds). APT-Reports 12: Use of Resource Niches in African Ecosystems - New Research Results from Tanzania, the Chad and Namibia. Freiburg, Germany.

Dongus S, Nyika D, Kannady K, Mtasiwa D, Mshinda H, Fillinger U, Drescher AW, Tanner M, Castro MC, Killeen GF, 2007. Participatory mapping of target areas to enable operational larval source management to suppress malaria vector mosquitoes in Dar es Salaam, Tanzania. Int J Health Geogr 6, 37.

Donnelly MJ, McCall PJ, Lengeler C, Bates I, D’Alessandro U, Barnish G, Konradsen F, Klinkenberg E, Townson H, Trape JF, Hastings IM, Mutero C, 2005. Malaria and urbanization in sub-Saharan Africa. Malar J 4, 12.

Dossou-Yovo J, Doannio JM, Diarrassouba S, Chauvancy G, 1998. The impact of rice fields on malaria transmission in the city of Bouaké, Côte d'Ivoire. Bull Soc Pathol Exot 91, 327-333.

Dossou-Yovo J, Doannio JM, Riviere F, Duval J, 1994. Rice cultivation and malaria transmission in Bouaké city (Côte d'Ivoire). Acta Trop 57, 91-94.

Drescher AW, 1998. Hausgärten in Afrikanischen Räumen Bewirtschaftung nachhaltiger Produktionssysteme und Strategien der Ernährungssicherung in Zambia und Zimbabwe, Pfaffenweiler, Centaurus.

Drescher AW, Holmer RJ, Iaquinta DL, 2006. Urban homegardens and allotment gardens for sustainable livelihoods: management strategies and institutional environments. In: Kumar BM and Nair PK (Eds). Tropical Homegardens: A Time-Tested Example of Agroforestry. Springer, New York, USA.

FAO, 2005. A system of integrated agricultural censuses and surveys. World Programme for the Census of Agriculture 2010, Volume 1. FAO Statistical Development Series. Food 
and Agriculture Organization of the United Nations, Rome, Italy.

Fillinger U, Kannady K, William G, Vanek MJ, Dongus S, Nyika D, Geissbühler Y, Chaki PP, Govella NJ, Mathenge EM, Singer BH, Mshinda H, Lindsay SW, Tanner M, Mtasiwa D, de Castro MC, Killeen GF, 2008. A tool box for operational mosquito larval control: preliminary results and early lessons from the Urban Malaria Control Programme in Dar es Salaam, Tanzania. Malar J 7, 20.

Geissbühler Y, Kannady K, Chaki PP, Emidi B, Govella NJ, Mayagaya V, Kiama M, Mtasiwa D, Mshinda H, Lindsay SW, Tanner M, Fillinger U, de Castro MC, Killeen GF, 2009. Microbial larvicide application by a large-scale, community-based program reduces malaria infection prevalence in urban Dar es Salaam, Tanzania. PLoS ONE 4, e5107.

Gerstl S, Cissé G, Tanner M, 2002. Economic impact of urban agriculture on home gardeners in Ouagadougou. Urban Agriculture Magazine 7.

Guerra CA, Gikandi PW, Tatem AJ, Noor AM, Smith DL, Hay SI, Snow RW, 2008. The limits and intensity of Plasmodium falciparum transmission: implications for malaria control and elimination worldwide. PLoS Med 5, e38.

Hardoy JE, Mitlin D, Satterthwaite D, 2001. Environmental problems in an urbanizing world - finding solutions for cities in Africa, Asia and Latin America, London, Earthscan.

Harpham T, 2009. Urban health in developing countries: what do we know and where do we go? Health Place 15, 107-116.

Hay SI, Guerra CA, Tatem AJ, Atkinson PM, Snow RW, 2005. Urbanization, malaria transmission and disease burden in Africa. Nat Rev Microbiol 3, 81-90.

Howorth C, Convery I, O’Keefe P, 2001. Gardening to reduce hazard: urban agriculture in Tanzania. Land Degr Develop 12, 285-291.

Ijumba JN, Lindsay SW, 2001. Impact of irrigation on malaria in Africa: paddies paradox. Med Vet Entomol 15, 1-11. Ijumba JN, Mosha FW, Lindsay SW, 2002. Malaria transmission risk variations derived from different agricultural practices in an irrigated area of northern Tanzania. Med Vet Entomol 16, 28-38.

ITC Enschede and University of Dortmund, 2008. Digital elevation model of Dar es Salaam. Enschede \& Dortmund, International Institute for Geo-Information Science and
Earth Observation Enschede and University of Dortmund. Jacob BG, Arheart KL, Griffith DA, Mbogo CM, Githeko AK, Regens JL, Githure JI, Novak R, Beier JC, 2005. Evaluation of environmental data for identification of Anopheles (Diptera: Culicidae) aquatic larval habitats in Kisumu and Malindi, Kenya. J Med Entomol 42, 751-755. Jacobi P, Amend J, Kiango S, 2000. Urban agriculture in Dar es Salaam: providing an indispensable part of the diet. In: Bakker N, Dubbeling M, Gündel S, Sabel-Koschella U and de Zeeuw H (Eds) Growing Cities, Growing Food: Urban Agriculture on the Policy Agenda. Feldafing, Deutsche Stiftung für internationale Entwicklung (DSE), Zentralstelle für Ernährung und Landwirtschaft.

Keating J, Macintyre K, Mbogo CM, Githeko A, Regens JL, Swalm C, Ndenga B, Steinberg LJ, Kibe L, Githure JI, Beier JC, 2003. A geographic sampling strategy for studying relationships between human activity and malaria vectors in urban Africa. Am J Trop Med Hyg 68, 357-365.

Keating J, Macintyre K, Mbogo CM, Githure JI, Beier JC, 2004. Characterization of potential larval habitats for Anopheles mosquitoes in relation to urban land-use in Malindi, Kenya. Int J Health Geogr 3, 9.

Kebede A, McCann JC, Kiszewski AE, Ye-Ebiyo Y, 2005. New evidence of the effects of agro-ecologic change on malaria transmission. Am J Trop Med Hyg 73, 676-680.

Keiser J, Utzinger J, Caldas de Castro M, Smith TA, Tanner M, Singer BH, 2004. Urbanization in sub-saharan Africa and implication for malaria control. Am J Trop Med Hyg 71, 118-127.

Keiser J, Utzinger J, Singer BH, 2002. The potential of intermittent irrigation for increasing rice yields, lowering water consumption, reducing methane emissions, and controlling malaria in African rice fields. J Am Mosq Control Assoc 18, 329-340.

Klinkenberg E, McCall PJ, Hastings IM, Wilson MD, Amerasinghe FP, Donnelly MJ, 2005. Malaria and irrigated crops, Accra, Ghana. Emerg Infect Dis 11, 1290-1293.

Klinkenberg E, McCall PJ, Wilson MD, Amerasinghe FP, Donnelly MJ, 2008. Impact of urban agriculture on malaria vectors in Accra, Ghana. Malar J 7, 151.

Klinkenberg E, Takken W, Huibers F, Toure YT, 2003. The phenology of malaria mosquitoes in irrigated rice fields in Mali. Acta Trop 85, 71-82.

Kyessi A, 1997. City expansion and urban agriculture in Dar 
es Salaam: lessons for planning. J Build Land Develop 4, 28-37.

Lindblade KA, Walker ED, Onapa AW, Katungu J, Wilson ML, 2000. Land use change alters malaria transmission parameters by modifying temperature in a highland area of Uganda. Trop Med Int Health 5, 263-274.

Lines J, Harpham T, Leake C, Schofield C, 1994. Trends, priorities and policy directions in the control of vectorborne diseases in urban environments. Health Policy Plan 9, 113-129.

Majambere S, Fillinger U, Sayer DR, Green C, Lindsay SW, 2008. Spatial distribution of mosquito larvae and the potential for targeted larval control in The Gambia. Am J Trop Med Hyg 79, 19-27.

Makani J, Matuja W, Liyombo E, Snow RW, Marsh K, Warrell DA, 2003. Admission diagnosis of cerebral malaria in adults in an endemic area of Tanzania: implications and clinical description. Q J Med 96, 355-362.

MARA/ARMA, 2002. MARA LITe for Africa. Johannesburg, South African Medical Research Council, Malaria Research Program.

Matthys B, Vounatsou P, Raso G, Tschannen AB, Becket EG, Gosoniu L, Cissé G, Tanner M, N'Goran EK, Utzinger J, 2006. Urban farming and malaria risk factors in a medium-sized town in Côte d'Ivoire. Am J Trop Med Hyg 75, 1223-1231.

Mboera LEG, Mlozi MRS, Senkoro KP, Rwegoshora RT, Rumisha SF, Mayala BK, Shayo EH, Senkondo E, Mutayoba B, Mwingira V, Maerere A, 2007. Malaria and agriculture in Tanzania: impact of land-use and agricultural practices on malaria burden in Mvomero district. Dar es Salaam, National Institute for Medical Research.

Mlozi MRS, Shayo EH, Senkoro KP, Mayala BK, Rumisha SF, Mutayoba B, Senkondo E, Maerere A, Mboera LEG, 2006. Participatory involvement of farming communities and public sectors in determining malaria control strategies in Mvomero district, Tanzania. Tanzania Health Research Bulletin 8, 134-140.

Mougeot LJA, 2000. Urban agriculture: definition, presence, potentials and risks. In: Bakker N, Dubbeling M, Gündel S, Sabel-Koschella U and de Zeeuw H (Eds) Growing Cities, Growing Food: Urban Agriculture on the Policy Agenda. Feldafing, Deutsche Stiftung für internationale Entwicklung (DSE), Zentralstelle für Ernährung und Landwirtschaft.
Mtasiwa D, Siegfried G, Tanner M, Pichette P, 2003. The Dar es Salaam city/region minimum package of health and related management activities: from managing diseases to managing health systems. Dar es Salaam, City Medical Office of Health.

Mukabana WR, Kannady K, Kiama GM, Ijumba JN, Mathenge EM, Kiche I, Nkwengulila G, Mboera L, Mtasiwa D, Yamagata Y, van Schayk I, Knols BG, Lindsay SW, Caldas de Castro M, Mshinda H, Tanner M, Fillinger U, Killeen GF, 2006. Ecologists can enable communities to implement malaria vector control in Africa. Malar J 5, 9.

Munga S, Minakawa N, Zhou G, Mushinzimana E, Barrack OO, Githeko AK, Yan G, 2006. Association between land cover and habitat productivity of malaria vectors in western Kenyan highlands. Am J Trop Med Hyg 74, 69-75.

National Bureau of Statistics, 2003. The 2002 population and housing census general report. Dar es Salaam, Government of Tanzania.

Patz JA, Strzepek K, Lele S, Hedden M, Greene S, Noden B, Hay SI, Kalkstein L, Beier JC, 1998. Predicting key malaria transmission factors, biting and entomological inoculation rates, using modelled soil moisture in Kenya. Trop Med Int Health 3, 818-827.

Rafatjah HA, 1988. Malaria vector control: environmental management. In: Wernsdorfer WH and McGregor I (Eds) Malaria: Principles and Practices of Malariology. Edinburgh, Churchill Livingstone.

Reyburn H, Mbakilwa H, Mwangi R, Mwerinde O, Olomi R, Drakeley C, Whitty CJ, 2007. Rapid diagnostic tests compared with malaria microscopy for guiding outpatient treatment of febrile illness in Tanzania: randomised trial. BMJ 334, 403.

Robert V, Awono-Ambene HP, Thioulouse J, 1998. Ecology of larval mosquitoes, with special reference to Anopheles arabiensis (Diptera: Culicidae) in market-garden wells in urban Dakar, Senegal. J Med Entomol 35, 948-955.

Robert V, Macintyre K, Keating J, Trape JF, Duchemin JB, Warren M, Beier JC, 2003. Malaria transmission in urban sub-Saharan Africa. Am J Trop Med Hyg 68, 169-176.

Sattler MA, Mtasiwa D, Kiama M, Premji Z, Tanner M, Killeen GF, Lengeler C, 2005. Habitat characterization and spatial distribution of Anopheles sp. mosquito larvae in Dar es Salaam (Tanzania) during an extended dry period. Malar $\mathrm{J} 4,4$. 
Sawio CJ, 1993. Feeding the urban masses? Towards understanding of the dynamics of urban agriculture and land-use change in Dar es Salaam, Tanzania. Worcester, Massachusetts, Clark University.

Sawio CJ, 1998. Managing urban agriculture in Dar es Salaam. Cities Feeding People Report Series 20. Ottawa, IDRC.

Smit J, Ratta A, Nasr J, 1996. Urban Agriculture: Food, Jobs and Sustainable Cities, New York, United Nations Development Programme (UNDP).

Snow RW, Guerra CA, Noor AM, Myint HY, Hay SI, 2005. The global distribution of clinical episodes of Plasmodium falciparum malaria. Nature 434, 214-217.

Sogoba N, Doumbia S, Vounatsou P, Bagayoko MM, Dolo G, Traore SF, Maiga HM, Toure YT, Smith T, 2007. Malaria transmission dynamics in Niono, Mali: the effect of the irrigation systems. Acta Trop 101, 232-240.

Stevenson C, Kinabo J, Nyange D, 1994. Urban Horticulture in Tanzania. Urban Vegetable Promotion Project, Dar es Salaam. Swallow B, Ochola S, 2006. Understanding the links between agriculture and health. Agroforestry, Nutrition, and Health. International Food Policy Research Institute, 2020 vision for food, agriculture and the environment, Focus 13, Brief 11 of 16, May 2006. Washington, International Food Policy Research Institute (IFPRI).

Trape JF, Lefebvre-Zante E, Legros F, Druilhe P, Rogier C, Bouganali H, Salem G, 1993. Malaria morbidity among children exposed to low seasonal transmission in Dakar, Senegal and its implications for malaria control in tropical Africa. Am J Trop Med Hyg 48, 748-756.

Trape JF, Zoulani A, 1987. Malaria and urbanization in central Africa: the example of Brazzaville. Part III: Relationships between urbanization and the intensity of malaria transmission. Trans R Soc Trop Med Hyg 81, 19-25.

UN, 2008. World Urbanization Prospects: The 2007 Revision Population Database. New York, United Nations, Department of Economic and Social Affairs, Population Division.

UNFPA, 2007. The State of the World Population.
Unleashing the Potential of Urban Growth. New York, United Nations Population Fund.

van den Berg H, Knols BG, 2006. The Farmer Field School: a method for enhancing the role of rural communities in malaria control? Malar J 5, 3.

van den Berg H, von Hildebrand A, Ragunathan V, Das PK, 2007. Reducing vector-borne disease by empowering farmers in integrated vector management. Bull World Health Organ 85, 561-566.

van der Hoek W, Sakthivadivel R, Renshaw M, Silver JB, Birley MH, Konradsen F, 2001. Alternate wet/dry irrigation in rice cultivation: a practical way to save water and control malaria and Japanese encephalitis? IWMI Research Report 47. Colombo, International Water Management Institute.

Walker K, Lynch M, 2007. Contributions of Anopheles larval control to malaria suppression in tropical Africa: review of achievements and potential. Med Vet Entomol 21, 2-21.

Wang SJ, Lengeler C, Mtasiwa D, Mshana T, Manane L, Maro G, Tanner M, 2006. Rapid urban malaria appraisal (RUMA) II: epidemiology of urban malaria in Dar es Salaam (Tanzania). Malar J 5, 28.

Warren M, Billig P, Bendahmane D, Wijeyaratne P, 1999. Malaria in Urban and Peri-Urban areas in Sub-Saharan Africa. Environmental Health Project Activity. Washington, DC, USAID.

WHO, 1982. Manual on Environmental Management for Mosquito Control with Special Emphasis on Malaria Vectors. WHO Offset Publication no. 66. World Health Organization, Geneva, Switzerland.

WHO, 2008. World Malaria Report 2008. World Health Organization, Geneva, Switzerland.

Ye-Ebiyo Y, Pollack RJ, Kiszewski A, Spielman A, 2003. Enhancement of development of larval Anopheles arabiensis by proximity to flowering maize (Zea mays) in turbid water and when crowded. Am J Trop Med Hyg 68, 748-752.

Zhou G, Munga S, Minakawa N, Githeko AK, Yan G, 2007. Spatial relationship between adult malaria vector abundance and environmental factors in western Kenya highlands. Am J Trop Med Hyg 77, 29-35. 